\title{
Aqabamycins A-G: novel nitro maleimides from a marine Vibrio species: I. Taxonomy, fermentation, isolation and biological activities
}

\author{
Wael Al-Zereini ${ }^{1}$, Clarisse Blanchine Fotso Fondja $\mathrm{Yao}^{2}$, Hartmut Laatsch ${ }^{2}$ and Heidrun Anke ${ }^{1}$ \\ In a screening of marine bacteria, a Vibrio species isolated from the surface of the soft coral Sinularia polydactyla collected \\ in the Red Sea was found to be a prolific producer of secondary metabolites with antibacterial and cytotoxic activities. \\ Seven novel maleimide derivatives named aqabamycin A (1a), aqabamycin B (1b), aqabamycin C (1c), aqabamycin D (1d), \\ aqabamycin $E$ (1e and $1 e^{\prime}$ ), aqabamycin $F(1 f)$ and aqabamycin $G(2)$ were isolated together with several known metabolites \\ such as 3-nitro- $1 \mathrm{H}$-indazole (3), indazole-3-carbaldehyde (4), phenyl-2-bis-indolylmethane (5a), turbomycin $B$ (5b), vibrindole \\ A (6), 1,4-dithiane (7), 3-(3-nitro-4-hydroxyphenyl)-2-propenoic acid (8), 3-nitro-4-hydroxybenzaldehyde (9), phenylacetic acid, \\ benzoic acid, 3-hydroxybenzoic acid and 4-hydroxycinnamic acid. The aqabamycins, except aqabamycin A, bear a nitro \\ group. Compounds 3, 4, 7 are described here for the first time from a natural source and vibrindole $A$ was found to have \\ cytotoxic activity.
}

The Journal of Antibiotics (2010) 63, 297-301; doi:10.1038/ja.2010.34; published online 30 April 2010

Keywords: antibacterial activity; aqabamycins; aromatic nitro compounds; cytotoxic activity; marine bacteria; Vibrio species

\section{INTRODUCTION}

Marine bacteria, in recent years, were the source of many new bioactive metabolites with interesting properties. ${ }^{1-3}$ Especially interesting are bacteria from biofilms. These bacteria colonize a large number of plants and sedentary animals and produce diverse chemical compounds that have a role in the protection of the host against pathogenic and fouling microorganisms. ${ }^{4}$ Species of the genus Vibrio comprise the majority of culturable bacteria in marine environments. ${ }^{5}$ Several Vibrio species were reported to produce tetrodotoxin and derivatives thereof; ${ }^{6-8}$ 1,1,3-tris(3-indol)-butane, 3,3-bis(3-indolyl) butane-2-one and other indoles have been recently reported from V. parahaemolyticus. ${ }^{9}$

In a screening of bacterial strains isolated from living marine surfaces in the Red Sea, extracts obtained from submerged cultures of strain WMBA exhibited antimicrobial and cytotoxic activities. Bioassay-guided isolation yielded 19 metabolites, many of which were novel compounds. In this paper we report the taxonomy of strain WMBA, its fermentation, the isolation and purification of the compounds, as well as their biological activities. The physico-chemical properties and the elucidation of the structures will be reported in a separate paper. ${ }^{10}$

\section{RESULTS AND DISCUSSION}

Strain WMBA forms light beige colonies on M1-agar. The cells are Gram-negative, mobile rods, $2.3-2.6 \mu \mathrm{m}$ (3.4) long and $1.0-1.7 \mu \mathrm{m}$ wide, nonsporogenic and facultative anaerobic. The strain does not accumulate poly- $\beta$-hydroxybutyrate and has no arginine dihydrolase system. It is oxidase and catalase positive but lacks a $\beta$-galactosidase activity, produces indole and reduces nitrate. It is a psychrotrophic strain unable to grow below $10^{\circ} \mathrm{C}$. Growth in media without marine salts is weak. The results of the biochemical and physiological characterization are summarized in Table 1 .

$16 \mathrm{~S}$ rRNA gene sequence analysis revealed that strain WMBA is very closely related to Vibrio species ( $99 \%$ similarity level). The nearest identified phylogenetic relatives were $V$. splindidus biovar II (Access. No. AB038030) isolated from North-western Pacific Ocean and Otsuch Bay, Japan, ${ }^{11}$ and V. shilonii (Access. No. AY911395), a pathogen that causes bleaching of the Mediterranean coral Oculina patagonica. ${ }^{12}$ Our strain differed from V. splindidus in the ability to use D-glucuronic acid and L-leucine and from $V$. shilonii in the ability to grow at salt concentrations higher than $6 \%$. Therefore, this strain represents a distinct species within the genus Vibrio.

\footnotetext{
IInstitute for Biotechnology and Drug Research (IBWF), Kaiserslautern, Germany and ${ }^{2}$ Institute of Organic and Biomolecular Chemistry, University of Göttingen, Göttingen, Germany

Correspondence: Professor H Anke, Institute for Biotechnology and Drug Research (IBWF), Erwin-Schroedinger-Strasse 56, Kaiserslautern D-67663, Germany. E-mail: anke@ibwf.de

Received 16 December 2009; revised 28 January 2010; accepted 26 March 2010; published online 30 April 2010
} 
Table 1 Biochemical and physiological characteristics of Vibrio sp. WMBA

\begin{tabular}{|c|c|c|c|}
\hline Characteristic & & Characteristic & \\
\hline $\mathrm{NaCl}$ requirement & - & Compound as $\mathrm{C}$ - and $\mathrm{N}$-source & \\
\hline Salinity tolerance & $7.5-10 \%$ & L-alanine & + \\
\hline Oxidation/fermentation & & L-leucine & + \\
\hline D-glucose & $+/+$ & L-proline & + \\
\hline D-lactose & $-1-$ & D-aspartic acid & + \\
\hline Sucrose & $-1-$ & L-lysine & - \\
\hline L-arabinose & $-1-$ & L-histidine & + \\
\hline D-xylose & $-1-$ & L-cysteine & + \\
\hline Fructose & $+/+$ & L-asparagine & - \\
\hline Maltose & $+/+$ & L-phenylalanine & - \\
\hline Rhamnose & $-1-$ & L-glutamine & + \\
\hline Mannitol & $+/+$ & L-tyrosine & + \\
\hline Glycerol & $+/+$ & Hydrolysis of & \\
\hline Raffinose & $-1-$ & Tween 40,80 & + \\
\hline Sorbitol & $-1-$ & Starch & - \\
\hline D-galactose & $+/+$ & Gelatine & + \\
\hline \multirow[t]{2}{*}{ Organic compound as $\mathrm{C}$-source } & & Esculin & + \\
\hline & & Esterase activity & + \\
\hline Sodium acetate & + & Arginine decarboxylase & - \\
\hline D-glucuronic acid & + & Lysine decarboxylase & - \\
\hline Succinic acid & + & $\beta$-Galactosidase & - \\
\hline Glycine & + & $\mathrm{H}_{2} \mathrm{~S}$ production & - \\
\hline DL-lactic acid & + & Indole production & + \\
\hline Oxalic acid & + & Nitrate reduction & + \\
\hline Sodium glutamate & + & Motility & + \\
\hline D-aspartic acid & + & Spore formation & - \\
\hline Sodium pyruvate & + & Poly- $\beta$-hydroxybutyrate & - \\
\hline
\end{tabular}

During a typical fermentation of strain WMBA in media with marine salts, the antifungal activity against Nematospora coryli reached its maximum after $36-48 \mathrm{~h}$ and the cultures were collected at this point. Bioactivity-guided fractionation resulted in the isolation of more than 15 compounds. The structures of the novel compounds named aqabamycins are given in Figure 1. The isolation procedure is described in 'Materials and methods' section. The isolation schemes for the crude extracts of cultures grown in M1 and B1 medium are given in Figures 2 and 3.

More common compounds that were obtained during the isolation such as phenylacetic acid, benzoic acid, 3-hydroxybenzoic acid and 3(4-hydroxyphenyl)-2-propenoic acid are not included in the description; 3-nitro- $1 \mathrm{H}$-indazole (3), indazole-3-carbaldehyde (4) and 1,4dithiane (7) are reported from a natural source for the first time. Vibrindole A (6) has been isolated from V. parahaemolyticus, but no biological activities have been reported so far. ${ }^{13}$

The total yields of compounds isolated from Vibrio sp. WMBA and the retention times measured by analytical HPLC are summarized in Table 2 .

All aqabamycins are novel compounds. They exhibited antibacterial and cytotoxic activities as shown in Tables 3 and 4 . Not all of the compounds were obtained in amounts to allow biological testing. The mixture of aqabamycin $\mathrm{E}$ (1e and $\mathbf{1} \mathbf{e}^{\prime}$ ) and aqabamycin $\mathrm{F}$ (1f) were the most active compounds. The MIC values toward bacteria varied between 3.15 and $25 \mu \mathrm{g} \mathrm{ml}^{-1}$. Fungi with the exception of $N$. coryli were only affected at concentrations of $50 \mu \mathrm{g} \mathrm{m}^{-1}$ or higher. Vibrindole A was not active up to $100 \mu \mathrm{g} \mathrm{ml}^{-1}$ (data not shown). As can be depicted from Table 4, L1210 cells were the most sensitive among the

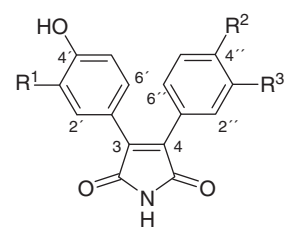

1a: $R^{1}, R^{2}, R^{3}=H$

1b: $\mathrm{R}^{1}=\mathrm{H}, \mathrm{R}^{2}=\mathrm{OH}, \mathrm{R}^{3}=\mathrm{NO}_{2}$

1c: $\mathrm{R}^{1}=\mathrm{NO}_{2}, \mathrm{R}^{2}, \mathrm{R}^{3}=\mathrm{H}$

1d: $\mathrm{R}^{1}, \mathrm{R}^{3}=\mathrm{NO}_{2}, \mathrm{R}^{2}=\mathrm{OH}$<smiles>O=C1NC(=O)C(c2c[nH]c3ccccc23)=C1c1ccc(O)c([N+](=O)[O-])c1</smiles>

2

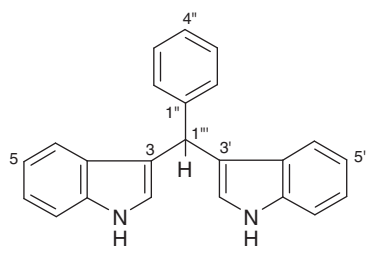

$5 a$

5b: $\mathrm{C}^{+}$instead of $\mathrm{CH}-1$ "'

Figure 1 Structures of compounds $1 \mathrm{a}, \mathbf{1 b}, \mathbf{1 c}, \mathbf{1 d}, \mathbf{1 e}$ and $\mathrm{e}^{\prime}, \mathbf{1 f}$ and 2-6.

tested cell lines. Vibrindole A (6) and aqabamycin E (1e and $\left.\mathbf{1} \mathbf{e}^{\prime}\right)$ were weakly but broadly cytotoxic. None of the compounds had nematicidal activity toward Caenorhabditis elegans and Meloidogyne incognita up to $100 \mu \mathrm{g} \mathrm{ml}^{-1}$ or phytotoxic activity. The latter was tested with Setaria italica and Lepidium sativum.

Together with a Salegentibacter species, ${ }^{14,15}$ Vibrio sp. WMBA is the second marine bacterium in our hands that abundantly produces aromatic metabolites with nitro substitutions. Except aqabamycin A, all aqabamycins possess a nitro substitution. Comparison of the activities of aqabamycins $\mathrm{A}$ and $\mathrm{C}$ shows that the nitro substitution increases the antibacterial activity whereas the cytotoxic activity is decreased.

Maleimides are a growing group of natural products with a variety of biological activities such as fungicidal, antibacterial, cytotoxic and even protein kinase $\mathrm{C}$ inhibitory activities. ${ }^{16}$ Not only bacteria are found among the producing organisms, also fungi have the capability to produce maleimides like the himanimides A, B and C, diarylmaleimide derivatives from the basidiomycete Serpula himantoides with weak antibacterial and antifungal activities. ${ }^{17}$

\section{METHODS}

\section{Producing organism}

The strain WMBA was isolated from the surface of the soft coral Sinularia polydactyla collected at a depth of $15 \mathrm{~m}$ in the Red Sea at Aqaba, Jordan. It has been deposited as WMBA-1 in the strain collection of the Institute of Biotechnology and Drug Research (IBWF), Germany.

\section{Taxonomy}

Morphological, biochemical and physiological tests. Morphological studies were carried out with a light microscope and a phase contrast microscope using 


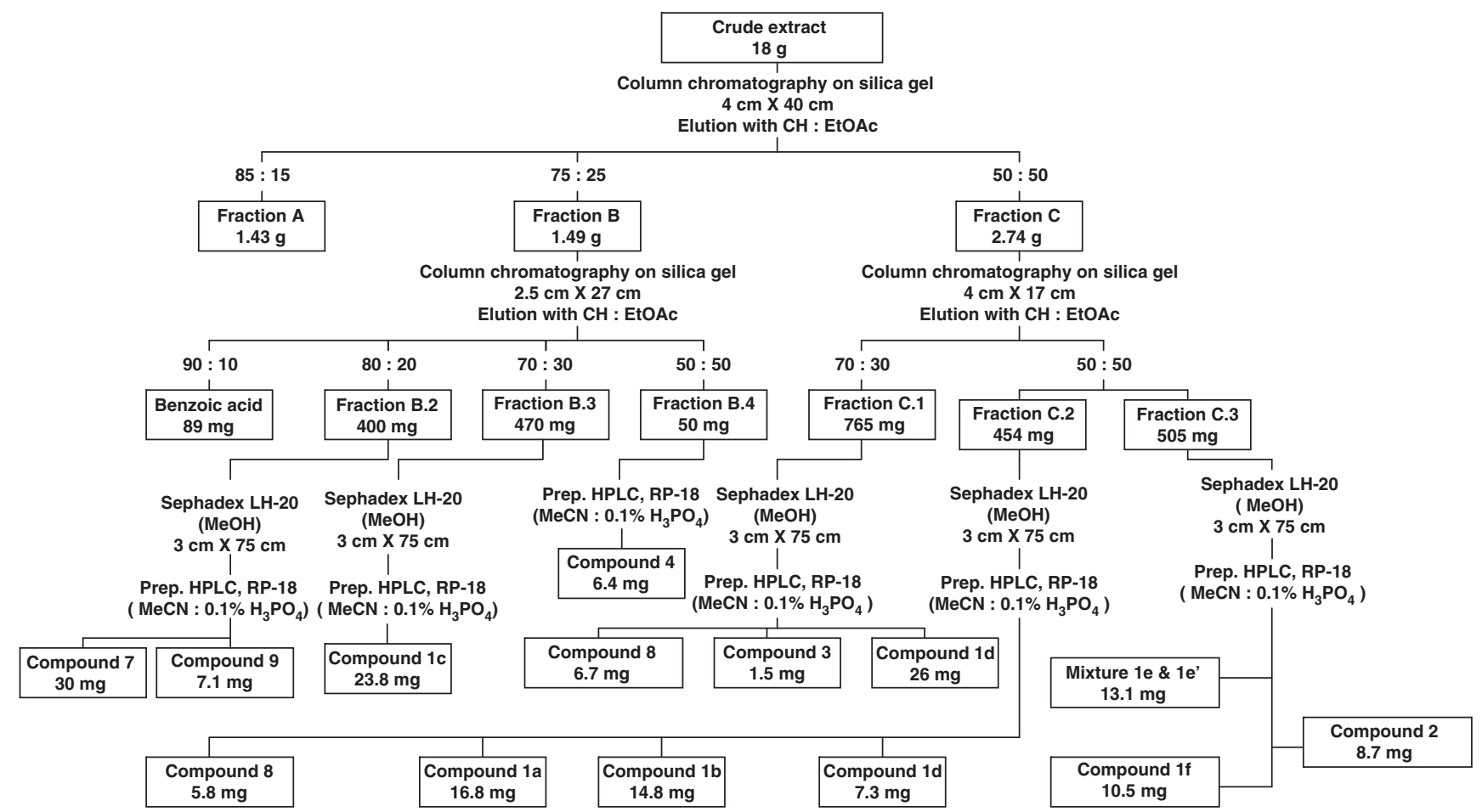

Figure 2 Isolation of compounds from fermentation of Vibrio sp. WMBA in medium B1.

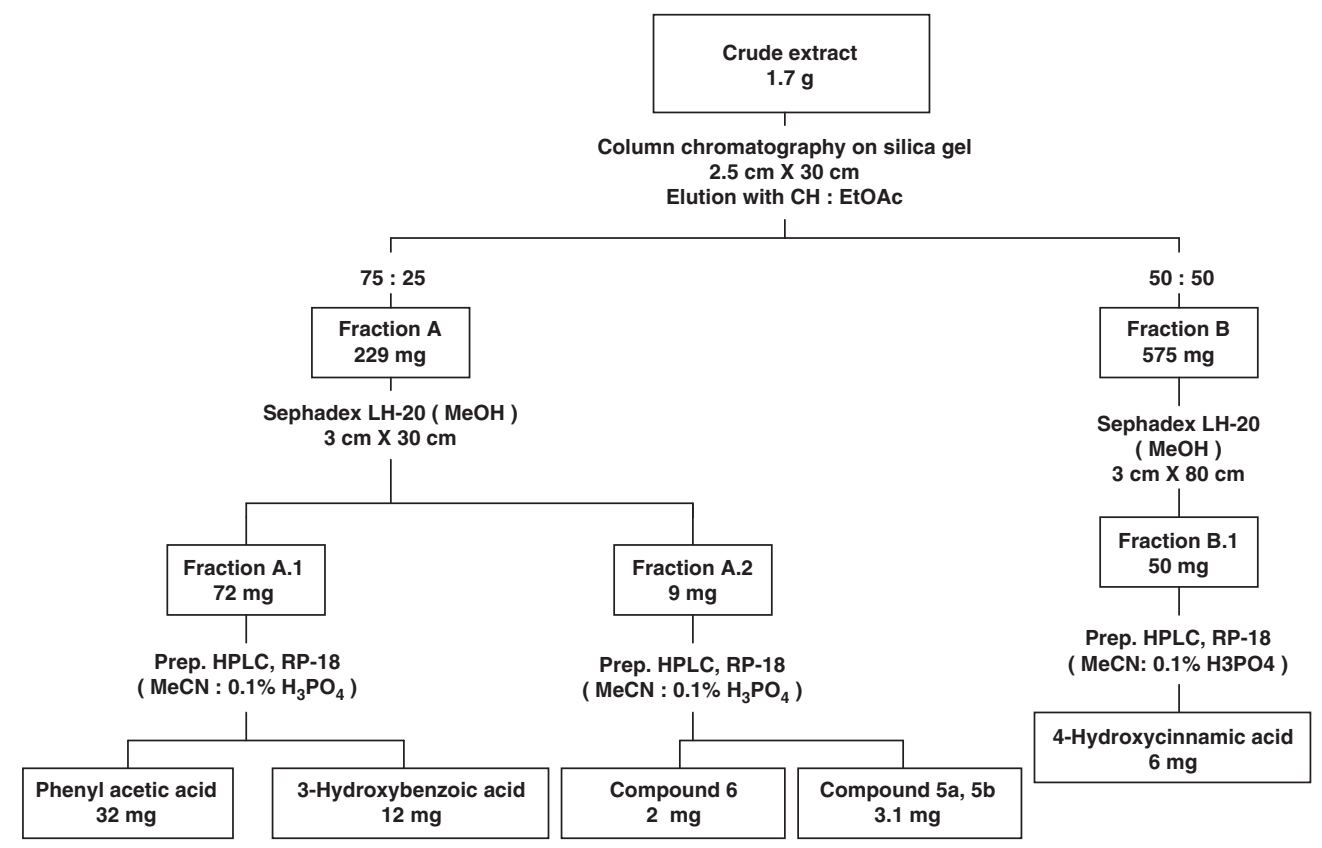

Figure 3 Isolation of compounds from fermentation of Vibrio sp. WMBA in medium M1.

cultures grown for 3-4 days at $25^{\circ} \mathrm{C}$ on modified M1-agar medium composed of yeast extract $0.5 \%$ (Difco, Detroit, MI, USA), tryptone $0.5 \%$ (Difco), $\mathrm{NaCl}$ $1 \%$, agar $2 \%$ in half strength artificial sea water, $\mathrm{pH} 7.2$. Half strength artificial sea water was prepared by dissolving $16.7 \mathrm{~g}$ of marine salt mixture, purchased from Tropic marine (Dr Biener, Wartenberg, Germany), in 11 distilled water.

Biochemical and physiological characteristics were determined using standard procedures as reported before. ${ }^{14}$

\section{Fermentation}

The strain was cultured in $500 \mathrm{ml}$ Erlenmeyer flasks containing $250 \mathrm{ml}$ of M1 medium on a rotary shaker $\left(120\right.$ r.p.m.) at $25^{\circ} \mathrm{C}$ for $36 \mathrm{~h}$. This culture was used to inoculate a Biolafitte C6 fermentor containing 201 of M1 medium or B1 medium composed of corn steep solids $0.5 \%$ (Sigma-Aldrich, Steinheim, Germany), A-Z amine $0.25 \%$ (Sigma-Aldrich), beef extract $3.8 \%$ (Difco), soy meal $0.1 \%$ (sojamin $50 \mathrm{~T}$, Lucas Meyer, Hamburg, Germany), yeast extract 
$0.25 \%$ (Hartge Ingredients, Hamburg, Germany), seaweed extract $0.25 \%$ (v/v) (Manufactum, Waltrop, Germany), marine salts mixture 3.33\%, pH value adjusted to 8.0. The fermentations were carried out at $25^{\circ} \mathrm{C}$ with aeration of $41 \mathrm{~min}^{-1}$ and agitation of 150 r.p.m.

During the fermentation process, samples $(150 \mathrm{ml})$ were taken every $12 \mathrm{~h}$. The culture fluid was separated from the bacterial cells by centrifugation $(16000 \mathrm{~g}, 10 \mathrm{~min})$. The supernatant was adjusted to $\mathrm{pH} 4$ and extracted with an equal volume of EtOAc. The organic phase was dried over $\mathrm{Na}_{2} \mathrm{SO}_{4}$, concentrated in vacuo at $40{ }^{\circ} \mathrm{C}$ and the resulting residue was dissolved in $\mathrm{MeOH}$ to a final concentration of $10 \mathrm{mg} \mathrm{m}^{-1}$. Aliquots corresponding to $300 \mu \mathrm{g}$ of the concentrated residue were used for the evaluation of the antifungal and antibacterial activities in the agar diffusion assay using $N$. coryli and Bacillus subtilis as test organisms.

Isolation and purification of the compounds

After $36-48 \mathrm{~h}$ of fermentation, when the OD started to decrease and/or the antimicrobial activity had reached its maximum, the cultures were collected. The biomass was separated by centrifugation and discarded. The supernatant (161) was adjusted to $\mathrm{pH} 4$ and extracted with EtOAc (101). After drying with $\mathrm{Na}_{2} \mathrm{SO}_{4}$, the organic phase was concentrated to dryness.

Table 2 Retention times ${ }^{\mathrm{a}}$ and yields of the aqabamycins and some of the other compounds isolated from Vibrio sp. WMBA

\begin{tabular}{lcc}
\hline Compound & Yield $\left(\mu \mathrm{I}^{-1}\right)$ & Retention time $(\mathrm{min})$ \\
\hline $\mathbf{1 a}$ & 210 & 10.95 \\
$\mathbf{1 b}$ & 195 & 10.65 \\
$\mathbf{1 c}$ & 300 & 12.43 \\
$\mathbf{1 d}$ & 415 & 11.70 \\
$\mathbf{1 e}, \mathbf{1 e}^{\prime}$ & 165 & 11.68 \\
$\mathbf{1 f}$ & 135 & 10.97 \\
$\mathbf{2}$ & 110 & 11.87 \\
$\mathbf{3}$ & 20 & 9.90 \\
$\mathbf{4}$ & 80 & 8.75 \\
$\mathbf{5 a}, \mathbf{5 b}$ & 155 & 15.67 \\
$\mathbf{6}$ & 100 & 14.54 \\
$\mathbf{7}$ & 375 & ND \\
$\mathbf{8}$ & 100 & 8.30 \\
$\mathbf{9}$ & 88.5 & 8.68 \\
\hline aHPLC conditions: RP-18, LiChroCart, $5 \mu$, 125 mm $\times 4$ mm, Merck, Darmstadt, Germany and \\
elution with O.1\% HCOOH (A) and MeCN (B) linear gradient 0-20 min 1-100\% B; flow rate \\
0.45 ml min $^{-1}$.
\end{tabular}

The combined crude extracts (18g) from five fermentations (80l) in B1 medium were applied onto a column with silica gel (Merck 60, 0.063-0.2 $\mu \mathrm{m}$; column $4 \mathrm{~cm} \times 40 \mathrm{~cm}$, Merck, Darmstadt, Germany). Elution with cyclohexane (CH)-EtOAc (85:15) yielded an inactive fraction A (agar diffusion assay with B. subtilis and N. coryli), which was discarded. Elution with CH-EtOAc (75:25) yielded fraction B (1.49g) and CH-EtOAc (50:50) fraction C (2.74 g), both exhibited antimicrobial activity and were further processed. Fraction B on fractionation on silica gel as above (column $2.5 \mathrm{~cm} \times 27 \mathrm{~cm}$ ) yielded $89 \mathrm{mg}$ of benzoic acid (elution with CH-EtOAc, 90:10), $400 \mathrm{mg}$ of fraction B.2 (CHEtOAc, 80:20), $470 \mathrm{mg}$ of fraction B.3 (CH-EtOAc, 70:30) and $50 \mathrm{mg}$ of fraction B.4 (CH-EtOAc, 50:50); 3-nitro-4-hydroxybenzaldehyde (9) and 1,4-dithiane (7) were obtained from B.2 by chromatography on Sephadex LH-20 (GE Healthcare, Munich, Germany) in $\mathrm{MeOH}$ (column size $3 \mathrm{~cm} \times 75 \mathrm{~cm}$ ) followed by HPLC on RP-18 $\left(7 \mu \mathrm{m}, 2.5 \mathrm{~cm} \times 25 \mathrm{~cm}\right.$, elution with $\mathrm{MeCN}(\mathrm{A}): 0.1 \% \mathrm{H}_{3} \mathrm{PO}_{4}$ (B), linear gradient in $40 \mathrm{~min}, 10 \% \mathrm{~A}-100 \% \mathrm{~A}$, flow rate $15 \mathrm{ml} \mathrm{min}^{-1}$ ), yield $7.1 \mathrm{mg}$ of compound 9 and $30 \mathrm{mg}$ of compound 7. Aqabamycin C (1c, $23.8 \mathrm{mg}$ ) was obtained from fraction B.3 by chromatography on Sephadex LH-20 (yield $98 \mathrm{mg}$ enriched product) and HPLC as above. Fraction B.4 yielded after HPLC (conditions as above) indazole-3-carbaldehyde $(4,6.4 \mathrm{mg})$. Fraction $\mathrm{C}$ afforded after silica gel chromatography (column $4 \mathrm{~cm} \times 17 \mathrm{~cm}$ ) and elution with $\mathrm{CH}-\mathrm{EtOAc}$ three fractions, C.1-C.3. These were each subjected to LH20 chromatography (see above) and the resulting active fractions were further

Table 4 Cyctotoxic activities $\left(\mathrm{IC}_{50}, \mu \mathrm{g} \mathrm{ml}^{-1}\right)$ of some of the compounds from Vibrio sp. WMBA

\begin{tabular}{lrrrrr}
\hline \multicolumn{5}{c}{ Cell line } \\
\cline { 2 - 6 } Compound & L1210 & Jurkat & MDA-MB321 & MCF-7 & Colo-320 \\
\hline 1a & 30 & $>100$ & $>100$ & 100 & 40 \\
1b & 100 & $>100$ & $>100$ & $>100$ & $>100$ \\
1c & 50 & $>100$ & $>100$ & $>100$ & $>100$ \\
1d & 15 & 60 & $>100$ & $>100$ & $>100$ \\
1e, e $^{\prime}$ & 15 & 20 & 25 & 20 & 50 \\
1f & 15 & 25 & $>100$ & $>100$ & 100 \\
$\mathbf{2}$ & 15 & 50 & $>100$ & $>100$ & 100 \\
$\mathbf{3}$ & 50 & 100 & $>100$ & $>100$ & 100 \\
$\mathbf{4}$ & 40 & 20 & $>100$ & $>100$ & 100 \\
$\mathbf{6}$ & 15 & 25 & 30 & 50 & 30 \\
$\mathbf{8}$ & 100 & $>100$ & $>100$ & $>100$ & $>100$ \\
$\mathbf{9}$ & 100 & $>100$ & $>100$ & $>100$ & $>100$ \\
\hline
\end{tabular}

Table 3 Antimicrobial activities (MIC, $\mu \mathrm{g} \mathrm{ml}^{-1}$ ) of some of the compounds from Vibrio sp. WMBA in the serial dilution assay

\begin{tabular}{|c|c|c|c|c|c|c|c|c|c|c|c|}
\hline Organism & $1 a$ & $1 b$ & $1 c$ & $1 d$ & $1 e, e^{\prime}$ & $1 f$ & 2 & 3 & 4 & 8 & 9 \\
\hline \multicolumn{12}{|l|}{ Bacteria } \\
\hline Bacillus subtilis & 50 & 100 & 25 & 50 & 6.25 & 12.5 & 25 & $>100$ & 100 & 100 & 25 \\
\hline Micrococcus luteus & 50 & 100 & 25 & 100 & 6.25 & 12.5 & 25 & $>100$ & $>100$ & $>100$ & 25 \\
\hline Escherichia coli & 100 & 100 & 50 & 100 & 12.5 & 12.5 & 50 & $>100$ & $>100$ & $>100$ & 50 \\
\hline Proteus vulgaris & 50 & 100 & 12.5 & 50 & 3.15 & 25 & 25 & $>100$ & $>100$ & $>100$ & 25 \\
\hline \multicolumn{12}{|l|}{ Fungi } \\
\hline Candida albicans & $>100$ & $>100$ & 100 & $>100$ & $>100$ & $>100$ & $>100$ & $>100$ & $>100$ & $>100$ & $>100$ \\
\hline Magnaporthe grisea & $>100$ & $>100$ & 50 & $>100$ & 50 & $>100$ & $>100$ & $>100$ & $>100$ & 25 & 5 \\
\hline Mucor miehei & $>100$ & $>100$ & 50 & $>100$ & 50 & $>100$ & 100 & $>100$ & $>100$ & $>100$ & 50 \\
\hline Nematospora coryli & 10 & 100 & 50 & 100 & 50 & 100 & 50 & $>100$ & 50 & 50 & 50 \\
\hline Paecilomyces variotii & 50 & $>100$ & 50 & $>100$ & 50 & $>100$ & $>100$ & $>100$ & $>100$ & $>100$ & 100 \\
\hline Phytophthora infestans & $>100$ & $>100$ & 100 & $>100$ & $>100$ & $>100$ & $>100$ & $>100$ & $>100$ & $>100$ & 50 \\
\hline Saccharomyces cerevisiae & $>100$ & $>100$ & 100 & $>100$ & $>100$ & $>100$ & $>100$ & $>100$ & $>100$ & $>100$ & 100 \\
\hline Ustilago nuda & $>100$ & $>100$ & 50 & $>100$ & $>100$ & $>100$ & $>100$ & $>100$ & 50 & $>100$ & 50 \\
\hline
\end{tabular}


processed by HPLC (see above). From fraction C.1 aqabamycin D (1d, $26 \mathrm{mg})$, 3-nitro-1 $\mathrm{H}$-indazole $(3,1.5 \mathrm{mg})$ and 3-nitro-4-hydroxycinnamic acid $(8,6.7 \mathrm{mg})$ were obtained. Fractions C.2 and C.3 yielded compound $8(5.8 \mathrm{mg})$, aqabamycins A (1a, $16.8 \mathrm{mg})$, B (1b, $14.8 \mathrm{mg}), \mathrm{D}(\mathbf{1 d}, 7.3 \mathrm{mg}), \mathrm{E}$ (1e and $\mathbf{e}^{\prime}$, mixture of isomers, $13.1 \mathrm{mg}), \mathrm{F}(\mathbf{1 f}, 10.5 \mathrm{mg})$ and $\mathrm{G}(\mathbf{2}, 8.7 \mathrm{mg})$.

The crude extract from a $20-1$ fermentation in medium M1 $(1.7 \mathrm{~g})$ was applied onto a column $(2.5 \mathrm{~cm} \times 30 \mathrm{~cm})$ with silica gel (see above). Elution with CH-EtOAc 75:25 and 50:50 yielded fractions A (229 mg) and B (575 mg). Further bioassay-guided fractionation (with B. subtilis and N. coryli as test organisms) of fractions A and B by chromatography on Sephadex LH-20 $(3 \mathrm{~cm} \times 30 \mathrm{~cm}$ and $3 \mathrm{~cm} \times 80 \mathrm{~cm}$, respectively) and elution with $\mathrm{MeOH}$ yielded $72 \mathrm{mg}$ of A.1 and $9 \mathrm{mg}$ of A.2, and $50 \mathrm{mg}$ of fraction B.1. All three fractions were further processed by HPLC on RP- $18(2.5 \mathrm{~cm} \times 25 \mathrm{~cm}$, elution with MeCN-0.1\% $\left.\mathrm{H}_{3} \mathrm{PO}_{4}\right)$. Phenylacetic acid $(32 \mathrm{mg})$ and 3-hydroxybenzoic acid $(12 \mathrm{mg})$ were obtained from fraction A.1, vibrindole A $(6,2 \mathrm{mg})$, and a mixture $(3.1 \mathrm{mg})$ of phenyl-2-bis-indolylmethane $(\mathbf{5 a})$ and turbomycin B $(\mathbf{5 b})$ from A.2. Finally, 4-hydroxycinnamic acid $(6 \mathrm{mg})$ was obtained from B.1.

The purity of all isolated compounds as checked by HPLC using a HP 1100 series instrument (Hewlett Packard, Waldbronn, Germany) equipped with a diode array detector (G1315B) fitted with an RP-18 column (LiChroCart, $5 \mu$, $125 \mathrm{~mm} \times 4 \mathrm{~mm}$, Merck; elution with $0.1 \% \mathrm{HCOOH}(\mathrm{A})$ and MeCN (B) linear gradient in $20 \mathrm{~min} 1-100 \% \mathrm{~B}$; flow rate $0.45 \mathrm{ml} \mathrm{min}^{-1}$ ) was $>98 \%$.

\section{Biological activities}

Antimicrobial activities, determined in the serial dilution assay, and cytotoxic activities were assayed as described earlier. ${ }^{18}$ Owing to low yields, not all of the compounds could be tested. L1210 (mouse lymphocytic leukemia), Jurkat (human acute T-cell leukemia) and Colo-320 (human colorectal adenocarcinoma) cells were grown in RPMI 1640 medium. MDA-MB-231 (human breast adenocarcinoma), and MCF-7 (human breast adenocarcinoma) cells were grown in DMEM medium. All media contained $10 \%$ fetal calf serum, $65 \mu \mathrm{g} \mathrm{ml}^{-1}$ of penicillin $\mathrm{G}$ and $100 \mu \mathrm{g} \mathrm{ml}^{-1}$ of streptomycin sulfate. The cells were incubated at $37^{\circ} \mathrm{C}$ in a humidified atmosphere containing $5 \% \mathrm{CO}_{2}$.

\section{ACKNOWLEDGEMENTS}

We thank the DAAD, Bonn (German Academic Exchange Service) and the Federal Minister for Science and Technology (BMBF, Berlin-Bonn) for financial support. We especially thank the members of the Marine Science Station in
Aqaba, Jordan, for the generous hospitality and support. The expert technical assistance of W Schuck and A Meffert is gratefully acknowledged.

1 Blunt, J. W. et al. Marine natural products. Nat. Prod. Rep. 25, 35-94 (2008).

2 Blunt, J. W. et al. Marine natural products. Nat. Prod. Rep. 26, 170-244 (2009).

3 Laatsch, H. Marine bacterial metabolites. in Frontiers in Marine Biotechnology (ed Proksch, P. et al.) 225-288 (Horizon Bioscience, Norfolk,, 2006).

4 Fusetani, N. Biofouling and antifouling. Nat. Prod. Rep. 21, 94-104 (2004).

5 Okada, K., lida, T., Kita-Tsukamoto, K. \& Honda, T. Vibrios commonly possess two chromosomes. J. Bacteriol. 187, 752-757 (2005).

6 Noguchi, T. et al. Occurrence of tetrodotoxin and anhydrotetrodotoxin in Vibrio sp. isolated from the intestines of a xanthid crab, Atergatis floridus. J. Biochem. 99, 311-314 (1986).

7 Yasumoto, T. et al. Bacterial production of tetrodotoxin and anhydrotetrodotoxin. Agric. Biol. Chem. 50, 793-795 (1986).

8 Lee, M. J. et al. A tetrodotoxin-producing Vibrio strain, LM-1, from the puffer fish Fugu vermicularis radiatus. Appl. Environ. Microbiol. 66, 16698-16701 (2000).

9 Veluri, R., Oka, I., Wagner-Döbler, I. \& Laatsch, H. New indole alkaloids from the North Sea bacterium Vibrio parahaemolyticus BI0249. J. Nat. Prod. 66, 1520-1523 (2003).

10 Fotso Fondja Yao, C. B., Al-Zereini, W., Fotso, S., Anke, H. \& Laatsch, H. Aqabamycins A-G: novel nitro maleimides from a marine Vibrio species: II. Structure elucidation. J. Antibiot. 63, 303-308 (2010).

11 Urakawa, H., Kita-Tsukamoto, K. \& Ohwada, K. Restriction fragment length polymorphism analysis of psychrophilic Vibrio and Photobacterium from the north-western Pacific Ocean and Otsuchi Bay, Japan. Can. J. Microbiol. 45, 67-76 (1999).

12 Kushmaro, A., Banin, E., Loya, Y., Stackebrandt, E. \& Rosenberg, E. Vibrio shiloi sp. nov., the causative agent of bleaching of the coral Oculina patagonica. Int. J. Syst. Evol. Microbiol. 51, 1383-1388 (2001).

13 Bell, R., Carmeli, S. \& Sar, N. Vibrindole A, a metabolite of the marine bacterium, Vibrio parahaemolyticus, isolated from the toxic mucus of the boxfish Ostracion cubicus. J. Nat. Prod. 57, 1587-1590 (1994).

14 Al-Zereini, W., Schuhmann, I., Helmke, E., Laatsch, H. \& Anke, H. New aromatic nitro compounds from Salegentibacter sp. T436, an arctic sea ice bacterium. I. Taxonomy, fermentation, isolation and biological activities. J. Antibiot. 60, 301-308 (2007).

15 Schuhmann, I. et al. Nitro derivatives from the Arctic ice bacterium Salegentibacter sp. isolate T436. J. Antibiot. 62, 453-460 (2009).

16 Davis, P. D. et al. Inhibitors of protein kinase C. 1. 2,3-Bisarylmaleimides. J. Med. Chem. 35, 177-184 (1992).

17 Aqueveque, P., Anke, T. \& Sterner, O. The himanimides, new bioactive compounds from Serpula himantoides (Fr.) Krast. Z. Naturforsch. 57c, 257-262 (2002).

18 Anke, H., Bergendorff, O. \& Sterner, O. Assay of the biological activities of guaiane sesquiterpenoids isolated from the fruit bodies of edible Lactarius species. Food Chem. Toxicol. 27, 393-398 (1989). 